\title{
Effects of the pathogenic water mold Saprolegnia ferax on survival of amphibian larvae
}

\author{
John M. Romansic ${ }^{1,3, *}$, Kristin A. Diez ${ }^{1}$, Elise M. Higashi ${ }^{1}$, James E. Johnson $^{2}$, \\ Andrew R. Blaustein ${ }^{1}$ \\ ${ }^{1}$ Department of Zoology, 3029 Cordley Hall, Oregon State University, Corvallis, Oregon 97331, USA \\ ${ }^{2}$ Department of Biological Sciences, Science Building, Room 338, 400 East University Way, \\ Central Washington University, Ellensburg, Washington 98926-7537, USA \\ ${ }^{3}$ Present address: Department of Biology, 4202 East Fowler Ave., SCA110, University of South Florida, \\ Tampa, Florida 33620, USA
}

\begin{abstract}
Infectious diseases are a significant threat to worldwide biodiversity. Amphibian declines, a significant part of current biodiversity losses, are in many cases associated with infectious disease. Water molds are one group of pathogens affecting amphibians on a worldwide basis. Although water molds have been studied extensively for their effects on host embryos, little information is available about how they affect post-embryonic amphibians. We tested the effects of one species of water mold, Saprolegnia ferax, in a comparative study of larvae of 4 amphibian species: Pseudacris regilla (Pacific treefrog), Rana cascadae (Cascades frog), Ambystoma macrodactylum (long-toed salamander), and R. aurora (red-legged frog). S. ferax can kill amphibians at the embryonic and juvenile life history stages, depending on the amphibian species. In the present study, a 1 wk exposure to $S$. ferax killed $P$. regilla larvae and a 2 wk exposure killed $R$. aurora larvae. Larvae of the other host species were unaffected after 1 wk of exposure to $S$. ferax. Our results suggest that $S$. ferax can kill amphibian larvae and further suggest that evaluation of how pathogens affect amphibians at the population level requires investigation at various life stages.
\end{abstract}

KEY WORDS: Water mold $\cdot$ Saprolegnia $\cdot$ Amphibian $\cdot$ Ambystoma macrodactylum $\cdot$ Pseudacris regilla $\cdot$ Rana aurora $\cdot$ Rana cascadae

Resale or republication not permitted without written consent of the publisher

\section{INTRODUCTION}

Biodiversity losses characterized by population declines, range reductions, and species extinctions are occurring at alarming rates (Raven 1987, Myers 1993, Singh 2002). One contributing factor is infectious disease (Daszak et al. 2000, Harvell et al. 2002, Altizer et al. 2003). As part of these worldwide losses in biodiversity, many amphibian populations are declining and disappearing (Houlahan et al. 2000). Although many factors probably contribute to amphibian population declines (Blaustein \& Kiesecker 2002), infectious disease may be a major cause (Daszak et al. 1999). For example, the pathogenic fungus Batrachochytrium dendrobatidis is associated with many amphibian population declines (e.g. Berger et al. 1998). However, other pathogens, including viruses, bacteria, trematodes, mesomycetozoans, and water molds, may also contribute to increased mortality and population declines in amphibians (e.g. Blaustein et al. 1994, Green et al. 2002).

Water molds (Stramenopila: Oomycota: Oomycetes: Saprolegniales) are fungus-like protists that inhabit aquatic habitats and moist soils (Dick 1990). Most aquatic water molds are saprobes that grow on dead organic matter (Dick 1990), and some water molds, including aquatic species, are capable of parasitism (Dick 1990, Johnson et al. 2002). Water molds that infect amphibians include Achlya flagellata, Aphanomyces sp., Saprolegnia ferax, S. parasitica, and probably a number of other species (Tiffney \& Wolf 1939, Blaustein et al. 1994, Berger et al. 2001, Lefcort et al. 1997). S. ferax contributes to massive mortality of frog embryos (Blaustein et al. 1994, Kiesecker \& Blaustein 1995). In addition, a mixed-species culture containing 
multiple species of both Achlya and Saprolegnia caused mortality and sublethal effects in embryos of Rana sylvatica (wood frog) and Bufo americanus (American toad) (Touchon et al. 2006, Gomez-Mestre et al. 2006). The effects of water molds on amphibian embryos appear to be influenced by several environmental factors, including temperature, $\mathrm{pH}$, ultraviolet$\mathrm{B}$ radiation, precipitation, plant cover, and oviposition behavior (Kiesecker \& Blaustein 1995, Green 1999, Kiesecker et al. 2001a, Ruthig 2006, additional references in Romansic et al. 2006).

In contrast to the extensive research on the effects of water molds on amphibian embryos, there is relatively little information available about how water molds affect post-embryonic amphibians. There is experimental evidence that Saprolegnia influences competitive interactions between larvae of Rana cascadae (Cascades frog) and Pseudacris regilla (Pacific treefrog), apparently by mediating densities of the competing species through differential effects on embryos (Kiesecker \& Blaustein 1999). Water mold infections have been reported in amphibian larvae in nature (Bragg \& Bragg 1958, Bragg 1962, Berger et al. 2001, Converse \& Green 2005), and occur occasionally in larvae of North American species (Converse \& Green 2005). Berger et al. (2001) reported massive mortality of Bufo marinus (cane toad) larvae associated with Aphanomyces sp. infection, and Saprolegnia has been found on dead amphibian larvae after mass mortality events (Bragg \& Bragg 1958, Bragg 1962). Romansic et al. (2006) demonstrated that Saprolegnia can kill larvae of $R$. aurora (northern red-legged frog), and Romansic et al. (2007) found that Saprolegnia can kill newly metamorphosed $R$. cascadae. The Saprolegnia isolates used in these studies were recently identified as $S$. diclina (used in the Romansic et al. 2006 study of larvae) and S. ferax (used in the Romansic et al. 2007 study of metamorphs, see 'Materials and methods' of the present paper for identification methods). As in amphibian embryos, the effects of Saprolegnia on amphibian larvae appear to be influenced by environmental stressors (Lefcort et al. 1997, Romansic et al. 2006). In addition, Walls \& Jaeger (1987) found that Saprolegnia infection in Ambystoma maculatum (spotted salamander) larvae was associated with bite wounds and mortality from aggressive A. talpoideum (mole salamander) larvae.

Recently published models suggest that mortality of post-embryonic amphibians contributes significantly to population declines (Biek et al. 2002, Vonesh \& De la Cruz 2002). Therefore, a full investigation of the potential effects of amphibian pathogens at the population level requires information on how these pathogens affect different life history stages, not just a single stage such as embryos. Therefore, we conducted a comparative study of the effects of Saprolegnia ferax in larvae of 4 amphibian species: Pseudacris regilla, Rana cascadae, Ambystoma macrodactylum (long-toed salamander), and R. aurora.

\section{MATERIALS AND METHODS}

Collection and maintenance of amphibians. Amphibians were kept in a laboratory maintained at approximately 13 to $15^{\circ} \mathrm{C}$ in 2002 and 10.5 to $14^{\circ} \mathrm{C}$ in 2003 . All water used in the study, unless otherwise noted, was tap water conditioned with NovAqua ${ }^{\circledR}$ and Amquel ${ }^{\circledR}$ water conditioners. Amphibians were kept under a natural photoperiod; however, Pseudacris regilla and Rana cascadae (used in Expt 1) were transferred from a natural photoperiod to a $12 \mathrm{~h}$ light: $12 \mathrm{~h}$ dark cycle at the start of Expt 1, as were Ambystoma macrodactylum larvae at the start of Expt 2. Prior to experimentation, frog embryos and larvae were kept in 381 aquaria (length $\times$ width $\times$ height $=50 \times 25 \times 31 \mathrm{~cm}$ ). Frog larvae were fed a mixture (3:1 by volume) of rabbit chow and Tetramin ${ }^{\circledR}$ fish flakes (hereafter: tadpole food) ad libitum. Metamorphosed frogs ( $\geq 50 \%$ tail resorption) were removed.

Pseudacris regilla larvae (Gosner development stages 25 to 35, Gosner 1960) were collected on 2 September 2002 from the Potholes subalpine meadow, located approximately $0.6 \mathrm{~km}$ NW of Todd Lake, Deschutes County, Oregon, USA ( 1980 m elevation). Prior to experimentation, $P$. regilla were maintained in aquaria filled with about $35 \mathrm{l}$ of water and not aerated. $P$. regilla were kept at a density of approximately 5 larvae $\mathrm{l}^{-1}$ water for $4 \mathrm{~d}$, then transferred to new tanks and maintained at a density of approximately 2.3 larvae $\mathrm{l}^{-1}$. Larvae were then transferred to new tanks every $7 \mathrm{~d}$.

Rana cascadae larvae were collected from the Potholes meadow on 23 August and 18 September 2002. $R$. cascadae collected on 23 August ranged from Gosner stages 25 to 35, and those collected on 18 September ranged from stages 36 to 40 . Prior to experimentation, $R$. cascadae were maintained unaerated in aquaria filled with about $35 \mathrm{l}$ of water. $R$. cascadae were housed at a density of approximately 1.6 larvae $\mathrm{I}^{-1}$ and transferred to new tanks with new water every 6 to 9 d. R. cascadae were kept at a lower density than Pseudacris regilla because they were larger in size.

Ambystoma macrodactylum larvae were collected on 28 August and 2 September 2002 from the Potholes meadow. To prevent cannibalism, which sometimes occurs among A. macrodactylum larvae (Walls et al. 1993), larvae were maintained individually in plastic cups (bottom diameter $=8 \mathrm{~cm}$, top diameter $=11 \mathrm{~cm}$, height $=11 \mathrm{~cm}$ ) filled with $0.6 \mathrm{l}$ of water. Prior to their use in Expt 2, A. macrodacylum were transferred to new cups with new water every 1 to $9 \mathrm{~d}$ and fed Tubifex sp. worms. 
Six Rana aurora egg masses (approximately 290 to 350 embyros mass ${ }^{-1}$, Gosner stages 18 to 21) were collected from Coast Pond ( 8 km south of Waldport, Lincoln County, Oregon, USA) on 16 January 2003. Embryos were placed in aerated aquaria filled with about 301 of water. $R$. aurora were transferred to new aquaria with new water every 7 to $8 \mathrm{~d}$ prior to being tested in Expt 3. Hatchlings were separated from unhatched individuals $15 \mathrm{~d}$ after hatching began and used in Expt 3. During the time between separation of hatchlings and Expt 3, R. aurora larvae ranged in density from 2.5 to 9.5 larvae $1^{-1}$.

Collection, isolation, and culture of Saprolegnia ferax. S. ferax was isolated from a water sample collected on 10 September 2002 at the shore of Lost Lake in the Oregon Cascade Range (Linn County, $1220 \mathrm{~m}$ elevation), a site where $S$. ferax has contributed to massive mortality of Bufo boreas embryos (Blaustein et al. 1994, Kiesecker \& Blaustein 1995, Kiesecker et al. 2001a). This isolate can kill juvenile frogs (Romansic et al. 2007). S. ferax was isolated using hemp seeds and YpG (yeast-glucose) agar media (Fuller \& Jaworski 1987) and identified as $S$. ferax using available keys and standard methods (Seymour 1970, Johnson et al. 2002). Identification was confirmed using a DNA barcoding procedure and comparison to available DNA sequences in GenBank (J. E. Johnson et al. unpubl. data). To obtain $S$. ferax for use in experiments, sterile hemp seeds were added to Petri dishes containing $S$. ferax cultures on YpG agar media to allow seeds to become inoculated with $S$. ferax. Seeds were then removed and added to standardized Petri dishes (diameter $=85 \mathrm{~mm}$, height $=12 \mathrm{~mm}, 50$ seeds per dish) filled approximately half full with ultrapure water and incubated for $7 \mathrm{~d}$ at approximately 20 to $23^{\circ}$ C. S. ferax hyphae grew between seeds in dishes, producing clumps of seeds connected by a mycelium of $S$. ferax containing hyphae and zoosporangia. These clumps of seeds were used to apply $S$. ferax treatments in experiments.

Experimental setup. To minimize handling stress, larvae were not measured at the start of experiments. Instead, within $1 \mathrm{~d}$ of the start of each experiment, leftover larvae not used in the experiment were measured for Gosner stage (frogs only) and total length in $\mathrm{mm}$. These measurements serve as estimates of these parameters for the exposed and control larvae at the start of the experiments. All experiments were checked once per day. Larvae were examined visually for hyphae consistent with water mold infection in amphibian larvae (Converse \& Green 2005). Dead larvae were removed and preserved in $70 \%$ ethanol. Larvae surviving to the end of their experiment were euthanized using MS-222 and preserved in $70 \%$ ethanol.
Expt 1. Mid-late stage Pseudacris regilla and Rana cascadae larvae: $P$. regilla and $R$. cascadae larvae were exposed to Saprolegnia ferax in a $2 \times 2$ factorial experiment that manipulated frog species and $S$. ferax. Experimental units consisted of plastic boxes (dimensions: 31 $\times 18 \times 8 \mathrm{~cm}$ ) filled with $2 \mathrm{l}$ of water to a depth of $4 \mathrm{~cm}$ and stocked with 6 larvae. Larvae were added to units haphazardly, except that each unit received either $P$. regilla or $R$. cascadae. On the day following the start of the experiment, 10 larvae of each species were haphazardly selected from the unused larvae. Selected $P$. regilla ranged in Gosner stage from 31 to 39 and in total length from 24.5 to $33.2 \mathrm{~mm}$, while selected $R$. cascadae ranged from stage 33 to 41 and in total length from 31.5 to $53.0 \mathrm{~mm}$. There were 2 pathogen treatments: $S$. ferax and control. There were 5 replicates of each treatmentfrog species combination, for a total of 20 experimental units. Treatment-frog species combinations were assigned to units randomly. The $S$. ferax treatment consisted of a clump of 50 hemp seeds overgrown with $S$. ferax hyphae and zoosporangia. The control treatment consisted of 50 sterile hemp seeds. A cage consisting of a small plastic box (length $\times$ width $\times$ height $=9.5 \times 9.5 \times$ $6.5 \mathrm{~cm}$ ) with sides of $1 \mathrm{~mm}$ fiberglass mesh and no top was placed in the center of each unit. Seeds were placed inside the cage to prevent larvae from feeding on $S$. ferax and thereby reducing the production of zoospores. However, the mesh sides of the cage allowed passage of $S$. ferax zoospores. The experiment began on 30 September 2002 and lasted for $7 \mathrm{~d}$. During this experiment, larvae were fed tadpole food ad libitum.

Expt 2. Ambystoma macrodactylum larvae: A. macrodactylum larvae were exposed to Saprolegnia ferax and control treatments. Experimental units consisted of plastic boxes and cages filled with water (as above). To prevent cannibalism, each unit was stocked with only 1 larva. Larvae were assigned to units randomly. The 4 remaining larvae not used in the experiment ranged from 40.8 to $58.2 \mathrm{~mm}$ in total length (mean $\pm \mathrm{SE}=51.6 \pm 3.9$ ). There were 2 treatments: $S$. ferax and control. Treatments were assigned to units randomly. There were 17 replicates of each treatment, for a total of 34 units. The $S$. ferax treatment consisted of a clump of 50 hemp seeds overgrown with $S$. ferax hyphae and zoosporangia. The control treatment consisted of 50 sterile hemp seeds. Six days after the experiment began, A. macrodactylum were fed Tubifex sp. The experiment lasted for $7 \mathrm{~d}$.

Expt 3. Stage 25 Rana aurora larvae: $R$. aurora larvae were exposed to Saprolegnia ferax and control treatments. Experimental units consisted of plastic boxes and cages filled with water (as above) and stocked with $5 R$. aurora larvae. Five of the 6 egg masses (Masses 1 through 5) were chosen at random and each unit received one haphazardly selected Gosner stage 25 larva ( 2 to $3 \mathrm{wk}$ post-hatching) from each 
of these masses. Units received larvae in random sequence. At the start of the experiment, 2 Gosner stage $25 R$. aurora not used in the experiment were haphazardly selected from each of Masses 1 through 5. These larvae ranged in total length from 15.7 to $25.1 \mathrm{~mm}($ mean $\pm \mathrm{SE}=20.1 \pm 0.80)$.

There were 2 treatments: Saprolegnia ferax and control. Treatments were assigned to units randomly. There were 5 replicates of each treatment, for a total of 10 units. The $S$. ferax treatment consisted of a clump of 50 hemp seeds overgrown with $S$. ferax hyphae and zoosporangia. The control treatment consisted of 50 sterile hemp seeds. After $7 \mathrm{~d}$, larvae were transferred to new boxes with new water and new cages and treatments were re-applied. Each unit received $0.03 \mathrm{~g}$ of tadpole food at the start of the experiment and immediately after transfer to new boxes. The experiment began on 7 February 2003 and lasted for $14 \mathrm{~d}$. Because the lack of $S$. ferax-induced mortality in some species in Expts 1 and 2 may have been due to short exposure times, the duration of Expt 3 was doubled to increase our ability to detect a possible effect of $S$. ferax on survival.

Densities of zoospores and zoospore cysts. For every application of a Saprolegnia ferax treatment, the combined number of zoospores and zoospore cysts of $S$. ferax were estimated using a cytometer for seed clumps randomly selected from the unused clumps in the batch used in the application (Table 1). These estimates were extrapolated to an estimated density of zoospores and cysts in the $S$. ferax treatment at application using the volume of water in units (Table 1).

Statistical analyses. In experiments where mortality occurred, survival data had heteroscedasticity that could not be removed by transformation. Therefore, for these experiments, we analyzed survival using nonparametric methods.

Survival in Expt 3 was analyzed using a rank-sum test. For Expt 1, we tested for an overall difference between the two treatments and a difference between treatments for each frog species using a multiple comparisons procedure. We used a Bonferroni adjustment (Ramsey \& Schafer 1997) to keep $\alpha=0.05$ for this pro-

Table 1. Saprolegnia ferax. Mean estimates of the number and density of the combined number of zoospores and zoospore cysts at each $S$. ferax treatment application

\begin{tabular}{|c|c|c|c|c|}
\hline \multirow[t]{2}{*}{ Expt } & \multirow[t]{2}{*}{ Application } & \multicolumn{3}{|c|}{ Zoospores and zoospore cysts } \\
\hline & & $\begin{array}{l}\text { Mean no. } \\
( \pm 1 \mathrm{SE})\end{array}$ & $\mathrm{n}$ & $\begin{array}{l}\text { Mean density } \\
\left(\mathrm{l}^{-1}\right)\end{array}$ \\
\hline 1 & Sole application & $1.3 \times 10^{8}$ & 1 & $6.6 \times 10^{7}$ \\
\hline 2 & Sole application & $1.3 \times 10^{8} \pm 6.5 \times 10^{6}$ & 3 & $6.5 \times 10^{7}$ \\
\hline \multirow[t]{2}{*}{3} & Initial application & $4.4 \times 10^{7} \pm 7.8 \times 10^{6}$ & 2 & $2.2 \times 10^{7}$ \\
\hline & Re-application & $3.3 \times 10^{7}$ & 1 & $1.6 \times 10^{7}$ \\
\hline
\end{tabular}

cedure. There were 3 pairwise comparisons of interest, so the p-value for rejection of null hypotheses in this procedure was set at 0.0167 . Pairwise comparisons were made using rank-sum tests. To investigate whether susceptibility to mortality from Saprolegnia ferax differed between Pseudacris regilla and Rana cascadae, we tested whether the effect of $S$. ferax on survival was different between the 2 species using a rank-based nonparametric contrast (Zar 1999).

\section{RESULTS}

\section{Expt 1. Mid-late stage Pseudacris regilla and Rana cascadae larvae}

Median survival was lower in the Saprolegnia ferax treatment compared to the control treatment (ranksum test, $Z=-2.4918, \mathrm{p}=0.0127$ ), indicating a main effect of $S$. ferax treatment (Fig. 1). For Pseudacris regilla, median survival was lower in the $S$. ferax treatment compared to the control treatment $(Z=-2.8347$, $\mathrm{p}=0.0046$ ), while for $R$. cascadae, survival was $100 \%$ in both the $S$. ferax and control treatments. However, the effect of the $S$. ferax treatment was not different in $P$. regilla compared to the $R$. cascadae treatment (nonparametric contrast, $S=-4.8941,0.10<\mathrm{p}<0.25)$.

In the Saprolegnia ferax treatment, there were $13 \mathrm{ob}-$ servations of hyphae consistent with $S$. ferax infection on live Pseudacris regilla (Table 2). All larvae that died were in the $P$. regilla-S. ferax treatment combination and were partially or completely eaten by conspecifics before inspection for hyphae. Hyphae were not observed on any of the 3 partially eaten carcasses found. Hyphae were not observed on $P$. regilla in the control treatment or on Rana cascadae in either treatment.

\section{Expt 2. Ambystoma macrodactylum larvae}

Survival was $100 \%$ in both the control treatment and the Saprolegnia ferax treatment. Hyphae were not observed on any Ambystoma macrodactylum (Table 2).

\section{Expt 3. Stage 25 Rana aurora larvae}

Median survival was lower in the Saprolegnia ferax treatment $(40.0 \%$, $95 \%$ CI: $0.0-40.0 \%)$ compared to the control treatment $(100 \%, Z=2.8247$, $\mathrm{p}=0.0047)$. In the $S$. ferax treatment, hyphae consistent with water mold infection were observed on live indi- 


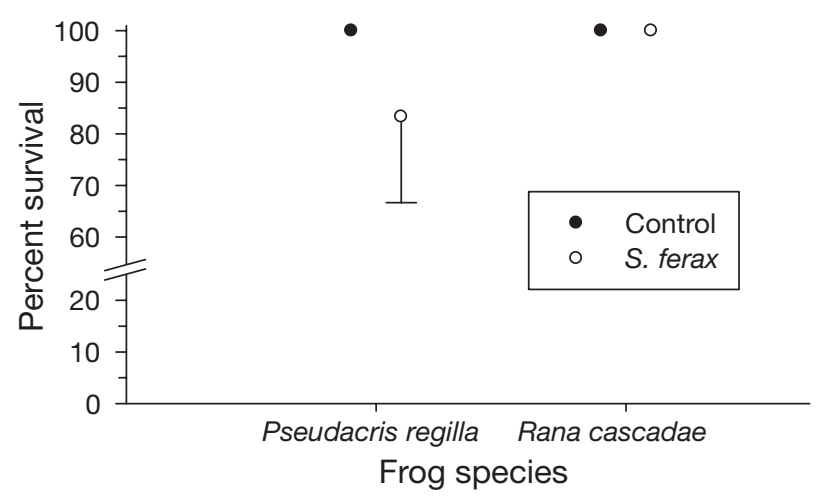

Fig. 1. Pseudacris regilla and Rana cascadae. Median survival of larvae exposed to Saprolegnia ferax and control treatments in Expt 1. The sole error bar is $95 \%$ CI

viduals 12 times and on 16 of 17 dead individuals (Table 2). One individual in the $S$. ferax treatment was completely eaten before inspection. No hyphae were observed in the control treatment.

\section{DISCUSSION}

Expt 1 suggests that 1 wk of exposure to Saprolegnia ferax killed mid-late stage Pseudacris regilla larvae. In contrast, 1 wk of exposure to $S$. ferax did not kill mid-late stage Rana cascadae, although there was insufficient statistical evidence to demonstrate that $P$. regilla was more susceptible to mortality from $S$. ferax than $R$. cascadae. In Expt 2, 1 wk of exposure to $S$. ferax did not kill Ambystoma macrodactylum larvae. Expt 3 suggests that 2 wk of exposure to $S$. ferax killed

Table 2. Pseudacris regilla, Rana cascadae, Ambystoma macrodactylum and $R$. aurora. Results of examinations for hyphae. Larvae that were completely eaten before inspection are not included. na: no carcasses

\begin{tabular}{|c|c|c|c|}
\hline Species & Treatment & $\begin{array}{l}\text { No./total no. (\%) } \\
\text { dead ind. with } \\
\text { hyphae }\end{array}$ & $\begin{array}{l}\text { Obs. of hyphae } \\
\text { on a live } \\
\text { individual }\end{array}$ \\
\hline \multicolumn{4}{|l|}{ Expt 1} \\
\hline \multirow[t]{2}{*}{$P$. regilla } & Control & na & 0 \\
\hline & S. ferax & $0 / 3^{a}(0)$ & $13^{\mathrm{b}}$ \\
\hline \multirow[t]{2}{*}{ R. cascadae } & Control & na & 0 \\
\hline & S. ferax & na & 0 \\
\hline \multicolumn{4}{|l|}{ Expt 2} \\
\hline \multirow[t]{2}{*}{ A. macrodacytlum } & Control & na & 0 \\
\hline & S. ferax & na & 0 \\
\hline \multicolumn{4}{|l|}{ Expt 3} \\
\hline R. aurora & $\begin{array}{l}\text { Control } \\
\text { S. ferax }\end{array}$ & $\begin{array}{c}\text { na } \\
16 / 17^{\mathrm{c}}(94)\end{array}$ & $\begin{array}{c}0 \\
12^{\mathrm{d}}\end{array}$ \\
\hline $\begin{array}{l}{ }^{a} \text { All } 3 \text { carcasses we } \\
{ }^{b} \text { At the end of the } \\
\text { cOne carcass with } \mathrm{h} \\
{ }^{\mathrm{d}} \text { At the end of the e }\end{array}$ & $\begin{array}{l}\text { ere partially } \\
\text { experiment, } \\
\text { hyphae was } \\
\text { experiment, }\end{array}$ & $\begin{array}{l}\text { eaten } \\
\text { one live individual } \\
\text { partially eaten } \\
\text { hyphae were not fo }\end{array}$ & $\begin{array}{l}\text { hyphae } \\
\text { on any live larv }\end{array}$ \\
\hline
\end{tabular}

early stage $R$. aurora larvae. In addition, hyphae consistent with $S$. ferax infection were observed on live $P$. regilla and live and dead $R$. aurora exposed to $S$. ferax treatments. Taken together, the results of the present study demonstrate that $S$. ferax can kill amphibian larvae and suggest that effects on larvae contribute to the overall effects of Saprolegnia on populations of its amphibian hosts.

Many of the pathogenic water molds have a wide host range and can persist and reproduce as saprobes on dead organic matter (Tiffney 1936, Dick 1990, Johnson et al. 2002). These characteristics give water molds considerable potential to affect amphibian populations. Water molds are likely to persist at high densities even if the density of one or more amphibian host species declines. Thus, if mortality from a pathogenic water mold contributes to a decline in an amphibian population, such mortality could continue as the population dwindles, potentially driving the host population to extinction. Persistence and reproduction as a saprobe and ability to cause mortality at low host densities are attributes that may aid the fungal pathogen Batrachochytrium dendrobatidis in driving to amphibian populations to extinction (Daszak et al. 1999).

Our results, together with previous research on amphibians and water molds (e.g. Kiesecker \& Blaustein 1995, Berger et al. 2001, Kiesecker et al. 2001b, Romansic et al. 2006, 2007) suggest that multiple life history stages of amphibians are susceptible to these pathogens. However, the life stage most susceptible to water molds may differ between amphibian species. Additionally, patterns of mortality may depend on the species of water molds present. Our results highlight the need to investigate possible effects on multiple life stages of the host species when evaluating the potential effects of pathogens on host populations. If only one life history stage of the host species is considered, the effect of a pathogen on the host population may be underestimated.

Although infectious diseases are a significant threat to global biodiversity (Daszak et al. 2000, Harvell et al. 2002, Altizer et al. 2003), the degree to which infectious diseases have contributed to the current biodiversity crisis is highly uncertain (Smith et al. 2006). Thus, there is an urgent need for better understanding of disease ecology so that the risk of disease-related biodiversity losses may be more accurately measured, and species and communities at risk of disease-related losses 
may be identified (Smith et al. 2006). There is evidence that anthropogenic environmental changes, pathogen pollution, and introduction of non-native pathogens by humans have already increased the impact of infectious disease in some species (e.g. Anagnostakis 1987, Conrad et al. 2005, Johnson et al. 2007). This evidence, combined with the prediction that climate change will cause an overall increase in the impact of infectious diseases on natural communities (Harvell et al. 2002), underscores the importance of making meaningful progress in our understanding of the ecology of infectious disease.

Acknowledgements. We thank J. Gonzalez, B. Bancroft, B. Han and M. Jones-Romansic for assistance and J. Spatafora and the Spatafora Lab for use of laboratory facilities for culturing. Additional help was provided by D. Hicks, R. Jorden, and E. Ripley. J.M.R. was supported by an EPA STAR Fellowship (FP-91640201-0). Additional funding was provided by D. Olson of the USDA Forest Service Pacific Northwest Research Station and grants from The National Science Foundation Integrated Research Challenges in Environmental Biology (NSF IRCEB) Program (DEB0213851 and IBN9977063).

\section{LITERATURE CITED}

Altizer S, Harvell D, Friedle E (2003) Rapid evolutionary dynamics and disease threats to biodiversity. Trends Ecol Evol 18:589-596

Anagnostakis SL (1987) Chestnut blight: the classical problem of an introduced pathogen. Mycologia 79:23-37

Berger L, Speare R, Daszak P, Green DE and others (1998) Chytridiomycosis causes amphibian mortality associated with population declines in the rain forests of Australia and Central America. Proc Natl Acad Sci USA 95: 9031-9036

Berger L, Speare R, Thomas A, Hyatt A (2001) Mucocutaneous fungal disease in tadpoles of Bufo marinus in Australia. J Herpetol 35:330-335

Biek R, Funk WC, Maxell BA, Mills LS (2002) What is missing in amphibian decline research: insights from ecological sensitivity analysis. Conserv Biol 16:728-734

Blaustein AR, Kiesecker JM (2002) Complexity in conservation: lessons from the global decline of amphibian populations. Ecol Lett 5:597-608

Blaustein AR, Hokit DG, O'Hara RK (1994) Pathogenic fungus contributes to amphibian losses in the Pacific Northwest. Biol Conserv 67:251-254

Bragg AN (1962) Saprolegnia on tadpoles again in Oklahoma. Southwest Nat 7:79-80

Bragg AN, Bragg WN (1958) Parasitism of spadefoot toads by Saprolegnia. Herpetologica 14:34

Conrad PA, Miller MA, Kreuder C, James ER and others (2005) Transmission of Toxoplasma: clues from the study of sea otters as sentinels of Toxoplasma gondii flow into the marine environment. Int J Parasitol 35:1155-1168

Converse KA, Green DE (2005) Diseases of tadpoles. In: Majumdar SK, Huffman JE, Brenner FJ, Panah AI (eds) Wildlife diseases: landscape epidemiology, spatial distribution, and utilization of remote sensing technology. The Pennsylvania Academy of Science, Easton, PA, p $72-88$
Daszak P, Berger L, Cunningham AA, Hyatt AD, Green DE, Speare R (1999) Emerging infectious diseases and amphibian population declines. Emerg Infect Dis 5:735-748

> Daszak P, Cunningham AA, Hyatt AD (2000) Emerging infectious diseases of wildlife: threats to biodiversity and human health. Science 287:443-449

Dick MW (1990) Oomycota. In: Margulis L, Corliss JO, Melkonian M, Chapman DJ (eds) Handbook of Protoctista. Jones \& Bartlett, Boston, MA, p 661-685

Fuller MS, Jaworski A (1987) Zoosporic fungi in teaching and research. Southeastern Publishing Corporation, Athens, GA

> Gomez-Mestre I, Touchon JC, Warkentin KM (2006) Amphibian embryo and parental defenses and a larval predator reduce egg mortality from water mold. Ecology $87: 2570-2581$

Gosner KL (1960) A simplified table for staging anuran embryos and larvae with notes on identification. Herpetologica 16:183-190

Green AJ (1999) Implications of pathogenic fungi for life-history evolution in amphibians. Funct Ecol 13:573-575

Green DE, Converse KA (2005) Diseases of amphibian eggs and embryos. In: Majumdar SK, Huffman JE, Brenner FJ, Panah AI (eds) Wildlife diseases: landscape epidemiology, spatial distribution, and utilization of remote sensing technology. The Pennsylvania Academy of Science, Easton, PA, p 62-71

> Green DE, Converse KA, Schrader AK (2002) Epizootiology of sixty-four amphibian morbidity and mortality events in the USA, 1996-2001. Ann N Y Acad Sci 969:323-339

> Harvell CD, Mitchell CE, Ward JR, Altizer S, Dobson AP, Ostfeld RS, Samuel MD (2002) Climate warming and disease risk for terrestrial and marine biota. Science 296: 2158-2162

> Houlahan JE, Findlay CS, Schmidt BR, Meyer AH, Kuzmin SL (2000) Quantitative evidence for global amphibian population declines. Nature 404:752-755

Johnson TW, Seymour RL, Padgett DE (2002) Biology and systematics of the Saprolegniaceae. Available at: http://dl. uncw.edu/digilib/biology/fungi/taxonomy\%20and\%20sy stematics/padgett $\% 20$ book

Johnson PTJ, Chase JM, Dosch KL, Hartson RB and others (2007) Aquatic eutrophication promotes pathogenic infection in amphibians. Proc Natl Acad Sci USA 104: 15781-15786

- Kiesecker JM, Blaustein AR (1995) Synergism between UV-B radiation and a pathogen magnifies amphibian embryo mortality in nature. Proc Natl Acad Sci USA 92: 11049-11052

Kiesecker JM, Blaustein AR (1999) Pathogen reverses competition between larval amphibians. Ecology 80:2442-2448

> Kiesecker JM, Blaustein AR, Belden LK (2001a) Complex causes of amphibian population declines. Nature 410:681-684

Kiesecker JM, Blaustein AR, Miller CL (2001b) Transfer of a pathogen from fish to amphibians. Conserv Biol 15: 1064-1070

Lefcort H, Hancock KA, Maur KM, Rostal DC (1997) The effects of used motor oil, silt, and the water mold Saprolegnia parasitica on the growth and survival of mole salamanders (Genus Ambystoma). Arch Environ Contam Toxicol 32:383-388

Myers N (1993) Biodiversity and the precautionary principle. Ambio 22:74-79

Ramsey FL, Schafer DW (1997) The statistical sleuth: a course in methods of data analysis. Duxbury Press, Belmont, CA 
Raven PH (1987) We're killing our world: the global ecosystem in crisis. MacArthur Foundation, Chicago, IL

Romansic JM, Diez KA, Higashi EM, Blaustein AR (2006) Effects of nitrate and the pathogenic water mold Saprolegnia on survival of amphibian larvae. Dis Aquat Org 68:235-243

Romansic JM, Higashi EM, Diez KA, Blaustein AR (2007) Susceptibility of newly-metamorphosed frogs to a pathogenic water mold (Saprolegnia sp.). Herpetol J 17: 161-166

Ruthig GR (2006) The influence of the environment and infectious disease on amphibian egg laying behavior. PhD dissertation, University of Virginia, Charlottesville, VA

Seymour RL (1970) The genus Saprolegnia. Nova Hedwigia 19:1-124

Singh JS (2002) The biodiversity crisis: a multifaceted review. Curr Sci 82:638-647

Smith KF, Sax DF, Lafferty KD (2006) Evidence for the role of infectious disease in species extinction and endangerment. Conserv Biol 20:1349-1357

Editorial responsibility: Alex Hyatt,

Geelong, Victoria, Australia
Tiffney WN (1936) A study of the species of Saprolegnia attacking fish. PhD dissertation, Harvard University, Cambridge, MA

Tiffney WN, Wolf FT (1939) Achlya flagellata as a fish parasite. J Elisha Mitchell Sci Soc 53:298-300

- Touchon JC, Gomez-Mestre I, Warkentin KM (2006) Hatching plasticity in two temperate anurans: responses to a pathogen and predation cues. Can J Zool 84:556-563

> Vonesh JR, De la Cruz O (2002) Complex life cycles and density dependence: assessing the contribution of egg mortality to amphibian declines. Oecologia 133:325-333, 627

Walls SC, Jaeger RG (1987) Aggression and exploitation as mechanisms of competition in larval salamanders. Can J Zool 65:2938-2944

Walls SC, Beatty JJ, Tissot BN, Hokit DG, Blaustein AR (1993) Morphological variation and cannibalism in a larval salamander (Ambystoma macrodactylum columbianum). Can J Zool 71:1543-1551

Zar HJ (1999) Biostatistical analysis, 4th edn. Prentice-Hall, Upper Saddle Creek, NJ

Submitted: February 17, 2008; Accepted: November 1, 2008 Proofs received from author(s): February 15, 2009 